Vol. IV, Part IV.

\title{
BULLETIN
}

\section{OF \\ The School of Oriental Studies, London Institution}

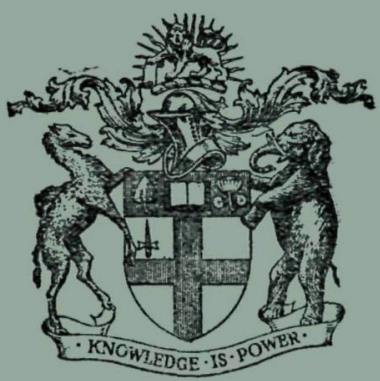

\section{TABLE OF CONTENTS}

PAPERS CONTRIBUTED-

PAGE

Notes on Japanese Literature (S. Yoshitake) . $\quad . \quad \ldots \quad$. $\quad . \quad$. 679

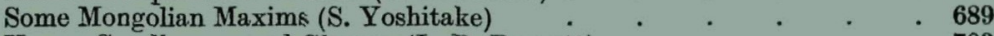

Yama, Gandharva, and Glaucus (L. D. Barnett) . . . . . 703

Fresh Light on Khawāşs Khān (E. Denison Ross) ‥ . . . . 717

A Portrait of Abu'l Fazl (communicated by T. W. Arnold) . . . 721

Taxation in Persia (Mostafa Khan Fateh) $\quad . \quad$. . . . . $\quad 723$

Studies in Contemporary Arabic Literature (H. A. R. Gibb) . 745

The Agastya Selection of Tamil Saivite Hymns (M. S. H. Thompson) 761

Dravidian Gender-words (Edwin H. Tuttle) . $\quad . \quad$. . . . . 769

The Gender of Arabic Infinitives in Urdu (T. Grahame Bailey) ～. 779

English Words in Panjābī (T. Grahame Bailey) . . . . . . 783

The Pronunciation of Marathi (A. Lloyd James and S. G. Kanhere) 791

Grammatical Sketch of the Jahai Dialect (Pater P. Schebesta) . $\quad$ - $\quad 803$

Chansons de Pagayeurs (J. Tanghe) $\quad . \quad$. $\quad . \quad$. $\quad . \quad$. $\quad .827$

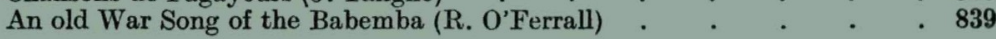

REVIEWS OF BOOKS AND OBITUARY. See next page.

Published by

The School of Oriental Studies, London Institution, Finsbury Circus, E.C. 2

1928

Price Six Shillings

Agents: Messrs. Luzac \& Co, 60 Great Russell Street, W.C.1. 


\section{BULLETIN \\ OF}

THE SCHOOL OF ORIENTAL STUdies, LONDON INSTITUTION. 


\title{
BULLETIN \\ OF THE
}

\section{SCHOOL OF ORIENTAL STUDIES,}

\section{LONDON INSTITUTION}

\section{VOLUME IV : 1926-28}

\author{
Published by
}

The School of Oriental Studies, London Institution, Finsbury Circus, E.C. 2.

Agents : Messrs. LuZAC \& Co., 46 Great Russell Street, W.C.I. 
Btephen AUgtin aND Bons, Lrd., PRinters, Hertgord. 


\section{CONTENTS OF VOLUME IV}

\section{PAPERS CONTRIBUTED}

A Corean Vocabulary. By S. Ogura

On the Adbhuta-Rāmāyana. By Sir George A. Grierson

Man as Willer. By C. A. F. Rhys Davids : . . . 29

The Mission of the Jesuit Fathers in China. Contributed by

Sir ARnold T. Wilson $\quad . \quad$. $\quad . \quad$. $\quad . \quad$. 47

The Passive Voice of the Jnanesvari. By W. Doderer . 59

The Government of "Prepositions" in Gujarati. By.

W. DodERET . . . . . . . . . 65

Notes on "The Assyrian Tree". By Sidney Sмith . $\quad$. 69

Note on the Statical and some other Participles in Hindustani.

By Lieut.-Col. D. C. Phillott . . . . . 77

Bengali Ballads. By W. Sutton Page $\quad$. $\quad$. $\quad$. $\quad$. $\quad 89$

A Selection from the T'ung Shu. Translated by J. P. Bruce 97

Some Remarks on Indian Music. By S. G. Kanhere . . 105

Kurdish Stories from my Collection. By Basile Nikitine . 121

Notes on the Pronunciation of Kanuri. By IdA C. WARD . 139

The Original Home of the Indo-Europeans. By JARL

Charpentier . . . . . . . . . 147

De Voulton's Noticia. Translated by LaURence Lockhart • 223

The Swahili Saga of Liongo Fumo. By A. Werner $\quad$. $\quad 247$

Deux residents mongols en Chine et en Asie Centrale. By

E. Blochet . . . . . . . . 257

The Jungle Tribes of the Malay Peninsula. By P. Schebesta 269

Notes on some Sanskrit MSS. on Alamkara. By SuSHIL

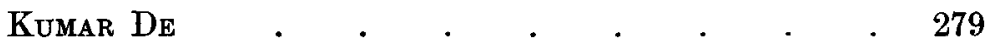

Jānakīharaṇa XVI. Edited by L. D. BARNETT . . . 285

Ajāmiḷa-mōkṣa-prabandha of Nārāyaña Bhatța. By

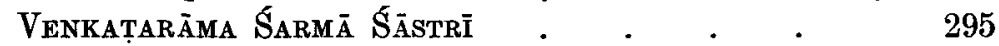

A Prayer of Śankarāchārya. By S. G. KanHere . . $\quad 301$

Wāman Pandit--Scholar and Marathi Poet. By S. G. Kanhere 305 . 
Stress-Accent in Indo-Aryan. By Banarsi Das J JiN .

The Development of English $t$. $d$, in North Indian Languages.

By T. Grahame Batley . . . . . .

Syām Sundar Dās's Bhăṣā Vigyān. Contributed by G. E.

LEeson . . . . . . . . . 331

'Omar Khayyam. By E. Denison Ross . . . . 433

An Arabic and a Persian metrical version of Burzoë's autobiography from "Kalila and Dimna". By E. Denison Ross .

A Chinese Treatise on Architecture. By W. Perceval Yetrs 441 Remarks on the Identification of some Jātaka Pictures. By

$J_{\text {ARL Charpentier }}$. $\quad . \quad . \quad . \quad . \quad . \quad .493$

A Burushaski Text from Hunza. By D. L. R. Lorimer . 505

Notes on Dardic. By R. L. Turner . . . . . . 533

The Grammar of the Jñāneśvarī. By W. Doderet . 543

Kodagu Peda, Tulu Pudar. By Edwin H. Tutrue . . $\quad 575$

The Rāmāyaṇa in Indonesia. By J. KATs . . . $\quad$. 579

A Study of the Oroha Language, Mala, Solomon Islands. By

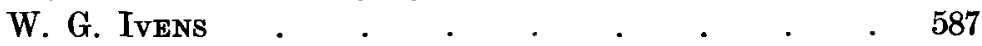

Some Readings of Jānakīharaṇa XVI. By S. K. Dé 611

Notes on Japanese Literature. By S. Yoshitake . . 679

Some Mongolian Maxims. By S. Yoshitake _. . . $\quad$. 689

Yama, Gandharva, and Glaucus. By L. D. BarnetT . . 703

Fresh Light on Khawāṣṣ Khān. By E. Denison Ross . . $\quad 717$

A Portrait of Abu'l Fazl. Communicated by T. W. Arnold 721

Taxation in Persia. By Mostafa Khan Fateh . . . 723

Studies in Contemporary Arabic Literature. By H. A. R. GIBB 745

The Agastya Selection of Tamil Śaivite Hymns. By M. S. H.

Thompson . . . . . . . . . . 761

Dravidian Gender-words. By Edwin H. Tutrte . . $\quad$. 769

The Gender of Arabic Infinitives in Urdu. By T. Grahame

BAILEY . . . . . . . . . . 779

English Words in Panjābī. By T. Grahame Bailey . . 783

The Pronunciation of Marathi. By A. Lloyd JAmes and

S. G. KANHERE . . . . . . . . .

Grammatical Sketch of the Jahai Dialect. By Pater P.

Schebesta . . . . . . . . . 803

Chansons de Pagayeurs. By J. Tanghe . . . . $\quad$. 827

An old War Song of the Babemba. By R. O'Ferrall . . 839 
T. G. Aravamuthan. The Kaveri, the Maukharis and the Sangam Age. By L. D. Barnett

Johannes Hertel. Die Arische Feuerlehre. By L. D. Barnett: 174

Henry Dodwell. A sketch of the History of India from 18581918. By William Foster

C. A. Kincaid and D. B. Parasnis. A History of the Maratha

People. Vol. III. By H. Dodwell . . . . . 178

G. E. Harvey. History of Burma. By H. Dodwell . $\quad 179$

Dhan Gopal MukeruI. My Brother's Face. By H. Dodwell . 180

Benoytosh Bhattacharyya. The Indian Buddhist Icono-

graphy. By L. D. Barnett . • • • • .

B. N. and B. B. Menta. The Modern Gujarati-English

Dictionary. 2 volumes. By W. Doderet . . . . 182

Christian Keysser. Wörterbuch der Kate Sprache. By

Sidney H. Ray . . . . . . . . .

Alice Werner. Volume VII (African) of the "Mythology of all Races ". By E. Denison Ross . . . . .

Maria von Tiling. Somali-Texte und Untersuchungen zur

Lautlehre. By A. Werner . $\quad . \quad$. $\quad . \quad$. $\quad$. 189

E. Torday. Causeries Congolaises. By A. Werner . . . 191

Gerhard LindBLom. Jakt-och Fångstmetoder bland

Afrikanska Folk. Del 1. By A. Werner . . .

192

Maurice Delafosse. La Culture Moderne: civilisations négro-africaines. By A. Werner . . . . . 193

A. Salmony. Sculpture in Siam. By C. O. Blagden . . 194

F. Ballod. The Volga Pompei. By M. Kasanin . . $\quad$. 197

Yuen Ren ChaO. A Phonograph Course in the Chinese National

Language. By J. P. Bruce . . . . . .

The Mathnawi of Jalálu'ddín Rūmí. Edited, etc., by Reynold A.

Nicholson. Vol. I. By C. E. Wilson . . . . 200

A. Berriedale Keith. Religion and Philosophy of the Veda and Upanishads. By Jarl Charpentier . . . .

Vikrama's Adventures. Edited and translated by Franklin Edgerton. By Jarl Charpentier . . . . . 346

Buddhistische Spätantike in Mittelasien von A. von Le Coq. Fünfter Teil : Neue Bildwerkè. By Jarl Charpentier

Further Dialogues of the Buddha. Translated by Lord

Chalmers. By C. A. F. Rhys Davids . . . . 
S. Tachibana. The Ethics of Buddhism. By C. A. F. Rhys Davids

Louis de la Vallée Poussin. Nirvänạa. By Th. Stcherbatsky

R. J. W Alker. Parnassus Biceps. By R. L. Turner

PAGE

E. Hultzsch. Inscriptions of Aśoka. New edition. By R. L. Turner

A. M. Hocart. Memoirs of the Archæological Survey of Ceylon.

Vol. II. By R. L. Turner . . . . . .

Baburam Saksena. The Verb in the Ramāyān of Tulsī Dās. By

R. L. Turner

Dunīcand. Painjābī aur Himdì kā Bhāṣā-Vijñāan. By R. L.

Turner

JuLes Bloch. "Voir" en Indo-Aryen. By R. L. Turner

Jules Bloch. Le Nom du Riz. By R. L. Turner . . .

G. Morgenstierne. Report on a Linguistic Mission to

Afghanistan. By R. L. Turner

JoHn SAMPson. The Dialect of the Gypsies of Wales.

By R. L. Turner . . . . . . .

Baburam Sarsena. Hindi and Urdu: The possibilities of their rapprochement. By R. L. Turner . . . . 375

Three Nepāli Reading Books. By R. L. Turner . . . 375

G. A. Grierson. Bihar Peasant Life. Second edition. By R. L. Turner . . . . . . . . 376

L. A. Waddell. Indo-Sumerian Seals Deciphered. By R. L. Turner . . . . . . . . . 376

Prabhat Chandra Chakravarti. Linguistic Speculations of the Hindus. By Siddheswar Varma . . . .

Atiya Begum Fyzee Rahamin. Music of India. By S. G.

Kanhere . . . . . . . . .

Keśeo Vināyak Godbole. Mahārāșța Śākuntala. By S. G. Kanhere.

Johannes Hertel. Die Methode der Arischen Forschung. By L. D. Barnett

Ernst Diez. Die Kunst Indiens. By L. D. Barnett .

Binode Behari Dutt. Town Planning in Ancient India. By

L. D. Barnett . . • • • • . .

Travel and Travellers in the Middle Ages. Edited by A. P.

Newton. By H. Dodwell 
H. B. Morse. Chronicles of the East India Company Trading to

Sir Duncan Campbell. Records of Clan Campbell in the

Service of the East India Company. By H. Dodwell .

S. H. Longriga. Four Centuries of Modern Iraq. By

H. Dodwell . $\quad$ - $\quad$. $\quad$. $\quad$. $\quad$. $\quad$. $\quad$ - 398

W. A. 'J. ARchbold. Outlines of Indian Constitutional History. By H. Dodwell . . . . . .

Sir George Forrest. State Papers of the Governors-General of India-Cornwallis. By H. Dodwell

J. D. B. Gribrle. History of the Deccan. Vol. II. By H. Dodwell

Arthur Mayhew. The Education of India. By H. Dodwell . 402

W. H. T. Gairdner. Phonetics of Arabic. By H. A. R. Gibb and A. Lloyd James .

P. PaUl Sbath. Al-Mashra'. By H. A. R. Gibb . . . 405

The Difnar of the Coptic Church. Edited by De Lacy O'Leary. By S. Gaselee . . . . . . . . . . 406

Rev. Frs. A. Reichart and Dr. M. Küsters, O.S.B. Elementary Kiswaheli Grammar. By F. Johnson . . . . 408 Bruno Gutmann. Das Recht der Dschagga. By A. Werner . Gerhard Lindblom. Notes on the Kamba Language. By A. Werner . . . . . . . . . 413 C. K. MEeK. The Northern Tribes of Nigeria. By A. Werner . 414 Tanganyika Territory. Report of the Education Committee. By A. Werner . . . . . . . .

The International Review of Missions. Special Africa Number.

By A. Werner . . . . . . . . 417

Hans Coudenhove. My African Neighbours. By A. Werner . 418 The Śatapatha Brāhmana in the Kānvīya Recension. Edited by Dr. W. Caland. Vol. I. By A. Berriedale Keith . . 615

W. Caland. Over het Vaikhānasasūtra. By A. Berriedale Keith 623

R. D. Ranade. A Constructive Survey of Upanishadic Philosophy. By A. Berriedale Keith. . . . .

Tr. Stcherbatsky. La Théorie de la Connaissance et la Logique chez les Bouddhistes tardifs. By A. Berriedale Keith . . . . . . . . . . 627 James M. MacPhail. Aśóka. By L. D. Barnett . . $\quad$. 628 
Radhakumud MookerJi. Hàrsha. By L. D. Barnett . . Māgha's Śiśupālavadha. Ins Deutsche übertragen von $\mathbf{E}$.

Hultzsch. By L. D. Barnett . . . . . . 630

Āścaryacūḍãmani. A Drama by Saktibhadra. By L. D. Barnett 631

Gaekwad's Oriental Series. By L. D. Barnett . . . 632

Further Dialogues of the Buddha. Translated ... by Lord

Chalmers. Vol. II. By C. A. F. Rhys Davids . . . . 633

Mukunda Ganesh Mirajkar. Samaśloki Gitā. By S. G.

Kanhere

Jagannāth Dās Ratnākar. Bihārī Ratnākar. By T. Grahame

Bailey

GIRIDHAR Dãs. Jarāsādh Vadh Mahākāvya. Edited by Vraj

Ratn Dās. By T. Grahame Bailey . . . . 638

Father PIERre Du Jarric, S.J. Akbar and the Jesuits.'

Translated by C. H. Payne. By A. Werner . . . 639

Georges Margouliès. Le Kou-wen chinois. By Lionèl Giles 640

Georges Margouliès. Le "Fou" dans de Wen-siuan. By

Lionel Giles

Charles Hose. Natural Man : A record from Borneo. By

C. 0. Blagden

L. A. Mulus. British Malaya, 1824-67. By C. O. Blagden

Edward Granville Browne. A Year amongst the Persians.

By Wolseley Haig

Tayyibāt, the Odes of Shaikh Musliḥu-d-Din Sa'di Shirāzi.

Translated by Sir Lucas White King. By Wolseley Haig

Muguamad Yahya ibn Sĩbak. Dastūr-i-'Ushshāq. Edited by

R. S. Greenshields. By Wolseley Haig . . . .

648

652

654

The Orthodox Patriarchate of Jerusalem. Report ... By

Arnold J. Toynbee.$\quad$. $\quad$. $\quad$ • $\quad$. . .

655

Francis Rennell Rodd. People of the Veil. By P. P. H.

Hasluck . . . . . . . . . 658

A. Moret and G. Davy. From Tribe to Empire. By H. Dodwell 659

Sir James George Frazer. The Worship of Nature. Vol. I. By

H. Dodwell.

Donald A. Mackenzie. The Migration of Symbols. By $\mathrm{H}$.

Dodwell

William Crooke. Religion and Folklore of Northem India.

By H. Dodwell . . . . . . . 
Francois Lexa. La Magie dans l'Egypte antique, de l'ancien empire jusqu'à l'époque copte. 3 tom. By A.Werner

PAGE

Nānàläs Chamantäl Mehta. Studies in Indian Painting. By T. W. Arnold

661

663

P. W. Schmidt, S.V.D. Die Sprachfamilien und Sprachenkreise der Erde. By C. O. Blagden.

664

Clement M. Doke. The Phonetics of the Zulu Language. By Lilias E. Armstrong . . . . . .

670

W. Y. Evans-Wentz. The Tibetan Book of the Dead. By H. Lee Shuttleworth

Th. Stcherbatsky. The Conception of Buddhist Nirvana. By C. A. F. Rhys Davids

Jal Dastur Cursetur Pavry. The Zoroastrian Doctrine of a Future Life. By C. A. F. Rhys Davids

Hemchandra Raychaudhuri. Political History of Ancient India. By C. A. F. Rhys Davids . . . . .

Ryukan Kimura. A Historical Study of the terms Hīnāyāna and Mahāyāna and the Origin of Mahāyāna Buddhism. By C. A. F. Rhys Davids .

Barhut Inscriptions. Edited by Benimadhab Barua and Kumar G. Sinha. By C. A. F. Rhys Davids . . . 857

The Book of the Cave of Treasures. Translated by Sir E. A. Wallis Budge. By L. D. Barnett .

Ernst Schierlitz. Die bildichen Darstellungen der Indischen Göttertrinität in der älteren ethnographischen Literatur. By J. Charpentier . . . . . . .

Ananda K. Coomaraswamy. Catalogue of the Indian Collections in the Museum of Fine Arts, Boston. Part V : Rājput Painting. By J. Charpentier

The Embassy of Sir Thomas Roe to India, 1615-19. Edited by Sir William Foster. By J. Charpentier . . . Warren Hastings' Letters to Sir John Macpherson. Edited by Professor Henry Dodwell, By W. Foster

Sir William Foster. The English Factories in India, 1668-9. By H. Dodwell

G. H. L. PITT-Rivers. T'he Clash of Cultures and the Contact of Races: By H. Dodwell

Cheikn Mohammed Abdou. Rissalat al Tawhid. Exposé de la Religión musulmane. Traduite de l'arabe . . . par B. Michel et le Cheikh Moustapha Abdel Razik. By A. S. Fulton . . . . . . . 
A. J. Toynbes. Survey of International Affairs, 1925. Vol. I :

The Islamic World. By A. T. Wilson

Muhammad Sharaf. An English-Arabic Dictionary of

Medicine, Biology, and Allied Sciences. By H. A. R. Gibb 876

G. R. Driver. A Grammar of the Colloquial Arabic of Syria and

Palestine. By H. A. R. Gibb . . . . .

Commandant Justinard. Manuel de Berbère Marocain. By

P. P. H. Hasluck

Sidney H..RAY. A Comparative Study of the Melanesian

Island Languages. By C. O. Blagden . . . .

James BaIkie. The Amarna Age. By C. J. C. Bennett . .

Université de Paris: Travaux et Mémoires de. l'Institut

d'Ethnologie

Em. G. Waterlot. Tome I: Les bas-reliefs des

bâtiments royaux d'Abomey. By A. Werner.

Renḱ Maunier. Tome III : La construction collective de la maison en Kabylie. By A. Werner.

René Trautmann. Tome IV: La Littérature populaire à la Côte des Esclaves. By A. Werner.

Arthur S. Cripps. An Africa for Africans. By A. Werner .

Diedrich Westermans. Die westlichen Sudansprachen und

ihre Beziehungen zum Bantu. By A. Werner . . . 893

M. HEepe. Jaunde-Wörterbuch. By A. Werner : . . 896

The late E. JAcottet. A Grammar of the Sesuto Language.

By A. Werner . . . . . . . . 897

G. Murray-Jardine. Abridged Swahili Grammar. By

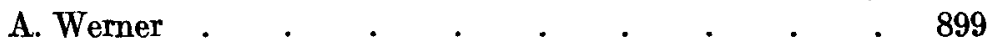

August Kuingenheben. Die Laute des Ful. By A. Werner . 900

S.P.C.K. Publications. By A. Werner . . . . . 900

NOTES AND QUERIES $\quad$ • . . . . . 207, 421673

\section{OBITUARY}

Edward Granville Browne, M.A., M.B., F.B.A., F.R.C.P. $\quad$. 217

Nawab Imadul Mulk Bahadur Sayed Husain Bilgrani . • . 431

Professeur Maurice Delafosse $\quad . \quad$. $\quad . \quad$. $\quad . \quad$. $\quad 675$

William Ernest Taylor $\quad . \quad$. . . . $\quad$. 903 